IP periodica polytechnica

Architecture

$38 / 1$ (2007) 33-35

doi: $10.3311 / p$ p.ar:2007-1.06

web: http://www.pp.bme.hu/ar

(C) Periodica Polytechnica 2007

RESEARCH ARTICLE

\section{Restricted freedom of choice}

Julianna Szabó

Received 2005-02-05

\section{Abstract}

The different development strategies of habitation areas are becoming more important in the midst of suburbanization processes in the Budapest agglomeration. In the following article three different development strategies are discussed based on their goals, ideological backgrounds, tools and effects on regional development.

After describing these developmental models attempt will be made to arrange them in the region and evaluate them in the context of regulatory, economic, political and social effects. Further assessment follows in terms of forming a coherent regional development policy.

In areas around the world's major cities, towns that are part of the suburbanization explosion are going through changes that are just as dramatic as those of the city centres. Their strategies have a strong influence on the forms of suburbanization, on the spatial structure of the changes, and on the success of central (regional, city centre) experiments in controlling globalization processes.

In the years since the political transition that began in 1989, the towns of the greater Budapest agglomeration have come up against frequent and often fundamental changes in the legal, regulatory, and economic environments. At the same time, they needed to - and still do need to - weigh the options and risks that accompany accelerated suburbanization, and balance between them. These options and risks regularly exceed the towns' normal capacities to deal with them. Because of the liberal municipal government system, the success of a chosen strategy certainly cannot be judged by whether it furthers the interests of the capital or of a region, but rather by the continuance of the town's viability, the satisfaction of the local residents with the uncontrolled or regulated processes, and the political impact of all the above on the local government election results.

\section{Keywords}

agglomeration · suburbanization - urban development strategies

\section{Julianna Szabó}

Department of Urban Studies, BME, 1111-H Budapest, Múegyetem rkp.3.,

\section{Determinant Conditions of Strategies}

The individual strategies of towns in the agglomeration naturally depend greatly on many factors - the given geographical situation, the regulatory environment, the financial possibilities, and national infrastructure developments. As these factors change, the strategies themselves are modified. However, upon examination of their reactions to the "environmental" effects of such things, certain regularities and typical strategies connected to the society and history of the town can be described. Familiarity with these is essential for co-ordinating regional-level planning perspectives with the town's own development tendencies.

The following factors can be used to describe the general situation of towns in the agglomeration of Budapest in the nineties, including their conditions and limitations:

\subsection{Administration:}

- complete administrative independence, and within this aspecialy urban development and financial independence,

- responsibility for and operating local services,

\subsection{Finance:}

- the town's financial independence,

- insufficiency of central resources for taking care of development tasks, and sometimes also for operating tasks,

- insufficiency of town tax revenue due to low tax base,

- low value of its own convertible assets such as real estate, town development:

- underdeveloped infrastructure and institutional services,

- significant increase in residential building lots' prices due to demand for them in the region,

- displacement of agriculture and especially horticulture due to the real estate market situation and changing lifestyles,

- the explosive growth of motor vehicles, 


\subsection{Politics:}

- the real estate ownership interests of the town's voting citizens and politicians after land re-privatization,

- citizen pressure to raise the quality of certain urban services to equal those of Budapest,

- pressure from owners of unincorporated lots for the area to be included in the building zone, and for infrastructure development,

- Budapest's ever-stronger repressive pressure in relation to agglomeration towns, or the threat of this pressure to stop suburbanization and withdraw certain towns' services or require payment for them.

Towns facing similar situations have three basic strategies they can follow.

\section{Typical Basic Strategies}

\subsection{Total Isolation Strategy:}

This strategy aims to eliminate the effects of the suburbanization process and preserve the town's pre-suburbanization size, demography, function, and society. Ideologically, primarily conservative values are present: the traditional country lifestyle, appreciation of agricultural activities; mistrust and often at times hostility towards new residents; protection of the residents, who largely have a low standard of living, due lack of money, and preservation of the conditions necessary for the poor lifestyle - one's own garden and animals, opportunities for inexpensive shopping, public transportation; promotion or revival of the local culture and traditions, etc. Alongside these values, however, some "modern" values familiar from the environmental protection movement may appear, primarily concerning protection of nature and the architectural environment, because these areas of environmental protection are most closely connected with the protection of the town's past and traditions, and also because these elements are easy for all to sense and are the best equipped for producing group identity and for political mobilization. This strategy's tools are typically kinds of prohibitions and restrictions.

\begin{tabular}{ll}
\hline Advantages, benefits & Disadvantages, risks \\
- community investment is not nec- & - resources available for community \\
essary, & goals are not expanded, \\
- the town's sociological-political & - the town becomes poorer, on both \\
balance can be expected to con- & the communal and the individual \\
tinue, & level, \\
- the condition of the environment is & - there is no improvement in the \\
not stressed by new dangers. & quality of the infrastructure and ser- \\
& vices available to the residents, \\
& - residents begin to move away, and \\
& the village becomes older.
\end{tabular}

\section{2 "Complete Change of Profile" Strategy:}

This strategy aims to lift up the town, make it richer, make up for what is lacking in services, and change the town's image, its character, function, demography and the quality level of its (public) services (and institutions). The capitalist consumer society's new values play an important role in the ideology of this strategy, as do the traditional values of urban planning inspiring growth and investment. The town sees its new function as providing and serving a residential and economic environment of a high enough level. Environmental protection (as a positive local value), agriculture (as a less lucrative activity that greatly disturbs a good quality residential environment), and all other factors are subordinate to this function. These towns do not consider suburbanization and the free real estate market a threat, but rather the chance to break out from decades of lagging behind. In keeping with this, the definitive values are quality, development, growth, and the urban lifestyle.

This strategy's tools are primarily offensive, interventionist politics which integrate the private market powers, so a primary condition for their implementation is a municipal government leadership with the right knowledge, will, and political acceptance.

\begin{tabular}{ll}
\hline Advantages, benefits & Disadvantages, risks \\
- the town can have a new profile, & - the municipal government must \\
- the municipal government's re- & take on a serious role in terms of or- \\
sources can grow significantly, & ganization, and oftentimes financing \\
- aging and impoverishment pro- & as well, \\
cesses can be stopped, & - in the case of bad marketing or \\
- the old part of the town can also & economic planning, the project could \\
grow from the new resources. & sink, the town could get into debt, \\
& - the town's political balance could \\
& be tipped in favour of the newcom- \\
& ers, \\
& - new environmental problems \\
could come up, & - the town could become a mono- \\
functional residential suburb of Bu- & dapest. \\
\hline
\end{tabular}

\section{3 "Laissez-faire" Strategy:}

The primary goal of this strategy is fulfilling the town's legal obligations while maintaining the financial balance, and perhaps improving its financial position. Though the previous two town strategies are generally much less defined by a conscious ideology, some principles can be uncovered in the background: questioning of the significance and the usefulness of town zoning laws, the rejection of an active market role and the use of its instruments by the local government. In this case, the town government understands itself to be the provider of the state services attributed to it by law, while on the other hand it understands suburbanization and its effects to be a change in the environment to which it needs to adapt while continuing to provide services. As a result of this, its strategic values are linked not to urban development, but to administrative operations - non-intervention, smooth flowing, staying problem-free, and avoiding conflict.

This strategy's tools are the town's traditional, non-market instruments, reducing the regulatory role to a minimum. 
Advantages, benefits

- the political pressure on the town council is reduced,

- the strategy requires minimal community investment.
Disadvantages, risks

- growth of harm to the environment,

- infrastructure in new areas is very difficult to develop without central direction, and at times things can lead to total stalemate, which can also have an effect on the older parts of the town,

- the sociological background of newly arrived residents is impossible to control, and this can mean new burdens for the municipal government.

\section{Breakdown by Strategies}

The strategy of individual habitation naturally can not be exactly identical to any of the above mentioned strategy. Even if the habitation is strictly committed to one course, in some cases depending on political, economical situation, habitations can decide to turn in another direction and apply another strategy. The arrangement of habitations depends mainly on their operational and decisional systems, therefore the development strategies are rarely explicit. Despite the fact that demarcation of the different strategies seems to be designated as arbitrary, those habitations adopting the same strategies can be easily specified using applied statistical methods:

Tab. 1. Areas mainly affected by Budapest suburbanization processes

\begin{tabular}{llll}
\hline Habitation & $\begin{array}{l}\text { Average number of } \\
\text { permanent resident } \\
\text { moving from Buda- } \\
\text { pest (1997-2000) }\end{array}$ & Habitation & $\begin{array}{l}\text { Average number of } \\
\text { permanent resident } \\
\text { moving from Buda- } \\
\text { pest per 1000 habi- } \\
\text { tants (1997-2000) }\end{array}$ \\
\hline Érd & 1724 & Telki & 83.6 \\
Budaörs & 734 & Leányfalu & 61.5 \\
Gyál & 705 & Budajenő & 60 \\
Dunakeszi & 675 & Veresegyház & 58 \\
Szigetszentmiklós & 674 & Diósd & 56.3 \\
Szentendre & 610 & Erdökertes & 56.2 \\
Szigethalom & 540 & Nagykovácsi & 56 \\
Veresegyház & 535 & Szigetmonostor & 52 \\
Fót & 502 & Szigethalom & 44.6 \\
Budakeszi & 416 & Pilisborosjenő & 43.9 \\
\hline
\end{tabular}

Source: Városkutatás Kft.

While the towns of the agglomeration change the intensity and methods of their town development strategies, they prove to be more constant in their choice of values. This relative stability is in part tied to political stability - in the agglomeration towns, especially the small towns, mayors and town councils frequently work on through several terms of office -, and in part it covers up the difficulties involved in changing strategies. Whether an isolationist, profile-changing, or "laissez-faire" strategy is followed by a town, decisions made will influence further opportunities for many years to come: once granted, building rights and tax breaks cannot be revoked, modification of large-scale zoning plans requires time and money, loans must be paid and existing institutions must be operated, while at the same time, missed opportunities for development and grants are usually impossible to make up for. For these reasons it is especially difficult to redirect a town's course away from a development-oriented strategy and into an isolationist, conservative direction. This kind of consistency in the strategies results in a consistency of roles on the map of the agglomeration. On this map, those following the "laissez-faire' strategy are in a definite majority, with the profile-changing and isolationist towns in smaller proportions. The towns following the first two strategies are naturally more likely to be in conflict with Budapest's wishes to curb suburbanization. The roots of the conflict are, however, in part precisely due to the fact that central decisions about town and infrastructure development do little to recognize the development strategies of agglomeration towns.

The development of migration figures allows us to conclude that the explosive growth in suburbanization which typified the second half of the 1990's is currently slowing. If this tendency continues, development areas appearing in agglomeration zoning plans cannot be expected to fill up. Though today the difference between towns following the profile-changing and the "laissez-faire" strategies seems insignificant, with the narrowing of development resources the difference will become more meaningful. The separation of towns favoured for residential or business purposes could also become more and more important, as could certain towns' increasingly definitive profile in this sense. Because of the further growth of motor vehicle use, towns' location along high-capacity traffic corridors or public transportation hubs will become a more and more meaningful factor influencing the towns' situation and their choices of strategies.

In the long run, further reduction in the number of isolationist towns can be presumed. According to the towns' environmental characteristics, they are generally good as residential areas, for recreational functions, and possibly as little "silicon valleys" concentrating on research and development. However, delaying steps toward development could make them targets of poverty segregation.

The number of "laissez-faire" strategy followers will also fall because of the strengthening of development competition, but their strategy and profile change will be made more difficult by the harmful legacy of ad-hoc town development decisions made in the meantime.

To sum up, we can say that in the Budapest agglomeration there will not be an American-type shifting of town structures to the degree that the analysis of zoning plans predicts today. The transitional period of the nineties leaves us with a far-reaching, difficult to manage urban legacy, not in the towns going through intensive profile-change, but in the target areas of poverty suburbanization and the damaged structure of towns unable to free themselves from the "laissez-faire" strategy. 